\title{
In-vitro nutrient degradability of complete feed containing myristic acid and tannins addition
}

\author{
Poespitasari Hazanah Ndaru, Siti Chuzaemi*, and Muhimmatu Mufidah \\ Faculty of Animal Science, Universitas Brawijaya, Malang 65145, Indonesia
}

\begin{abstract}
The purpose of this research was to determine the influence of Myristic acid and the source of condensed tannin on corn straw basedcomplete feed on nutrient content and in vitro digestibility. The method which was used in this experiment was randomized block design with four treatments and three replications. The treatment consisted of $\mathrm{T} 0$ complete feed $(40 \%$ corn straw $+60 \%$ concentrate), $\mathrm{T} 1$ complete feed ( $40 \%$ corn straw $+60 \%$ concentrate + myristic acid $30 \mathrm{~g} / \mathrm{Kg} \mathrm{DM})$, T2 complete feed ( $40 \%$ corn straw $+50 \%$ concentrate + calliandra leaf meal $10 \% / \mathrm{Kg}$ DM and myristic acid $30 \mathrm{~g} / \mathrm{Kg} \mathrm{DM})$, T3 complete feed (40\% corn straw $+45 \%$ concentrate + calliandra leaf meal $15 \% / \mathrm{Kg} D$ and myristic acid $30 \mathrm{~g} / \mathrm{Kg}$ $\mathrm{DM}), \mathrm{T} 4(40 \%$ corn straw $+40 \%$ concentrate + calliandra leaf meal $20 \% / \mathrm{Kg}$ $\mathrm{DM}$ and myristic acid $30 \mathrm{~g} / \mathrm{Kg} \mathrm{DM}$ ). Based on the result, it could be concluded that calliandra leaf meal $15 \% / \mathrm{Kg} \mathrm{DM}+$ Myristic acid $30 \mathrm{~g} / \mathrm{Kg}$ $\mathrm{DM}$ on the complete feed (T3) was the best treatment based on nutrient content and increase of dry matter digestibility, but not an effect of organic matter digestibility.
\end{abstract}

\section{Introduction}

Corn is a type of agricultural crop whose main results are utilized by humans, while byproducts include corn straw, cob, corn seeds that can be used as animal feed [1]. The productivity of corn crops every year has increased significantly. National corn production in 2014 was 19.0 million tons. The increase in corn production continued to grow in 2016, which was 23.6 tons, then in 2017, it reached 28.9 million tons, and in 2018 , there was a significant increase of 30 million tons. In Indonesia, corn straw frequently becomes one of the feed compositions in complete feed. The complete feed consists of a mixture of forages and concentrates high in nutrients with a balanced ratio and arranged according to livestock needs [8].

At the time, the production of methane gas from cattle become a global issue because cattle consume a high of crude fibre. Therefore, efforts are needed to reduce methane gas by manipulating animal feed strategy and adding active compounds into the feed $[2,3]$. The addition of myristic acid to complete feed can affect the increase in the nutrient content of the feed and reduce $\mathrm{CH}_{4}$ [9]. At the same time, the supplementation of concentrate with

\footnotetext{
*Corresponding author: schuzaemi@ub.ac.id
} 
calliandra can affect the increase in the value of crude protein content and feed degradation [10].

\section{Materials and methods}

\subsection{Materials}

The material used in this study was a complete feed consisting of corn straw and concentrate composed of rice bran, copra meal, palm oil meal, soybean meal, coffee husk, cassava, urea, and molasses. Complete feed is composed of iso-protein with a CP content of $14-15 \%$. At the same time, the additional ingredients include calliandra leaf meal, myristic acid, and cow rumen fluid. Complete feed was formulated become five treatments, and then it was analysed to determine the nutrient content of the feed and the value of feed degradation.

\subsection{Method}

This study used an experimental method with RBD (Randomized Block Design) with five treatments repeated three times. The complete feed formulation is as follows:

T0 : complete feed ( $40 \%$ corn straw $+60 \%$ concentrate)

$\mathrm{T} 1$ : complete feed $(40 \%$ corn straw $+60 \%$ concentrate $+0 \%$ calliandra leaf meal $)+$ myristic acid $30 \mathrm{~g} / \mathrm{kg} \mathrm{DM}$ diet.

$\mathrm{T} 2$ : complete feed $(40 \%$ corn straw $+50 \%$ concentrate $+10 \%$ calliandra leaf meal $)+$ myristic acid $30 \mathrm{~g} / \mathrm{kg}$ DM diet.

$\mathrm{T} 3$ : complete feed $(40 \%$ corn straw $+45 \%$ concentrate $+15 \%$ calliandra leaf meal $)+$ myristic acid $30 \mathrm{~g} / \mathrm{kg} \mathrm{DM}$ diet.

T4 : complete feed $(40 \%$ corn straw $+40 \%$ concentrate $+20 \%$ calliandra leaf meal $)+$ myristic acid $30 \mathrm{~g} / \mathrm{kg}$ DM diet.

Table 1. Nutrient content of complete feed ingredients

\begin{tabular}{|l|c|c|c|c|c|c|}
\hline \multicolumn{1}{|c|}{ Feedstuffs } & DM (\%) & OM* $^{*}$ & Ash $^{*}$ & CP* $^{*}$ & CF $^{*}$ & EE* \\
\hline Coffee husk & 94.14 & 89.42 & 10.58 & 10.11 & 34.00 & 1.50 \\
\hline Rice bran & 90.63 & 87.40 & 1.60 & 10.15 & 16.20 & 13.00 \\
\hline Cassava waste & 92.59 & 82.87 & 7.13 & 1.76 & 25.39 & 0.44 \\
\hline Soybean meal & 93.53 & 91.62 & 8.38 & 47.53 & 4.04 & 2.58 \\
\hline Palm kernel meal & 95.39 & 94.97 & 5.03 & 14.24 & 20.91 & 10.01 \\
\hline Copra meal & 95.69 & 92.23 & 7.77 & 22.12 & 21.78 & 2.45 \\
\hline Urea & 99.88 & 99.93 & 0.07 & 244.60 & 0.00 & 0.00 \\
\hline Molasses & 78.47 & 84.57 & 15.43 & 4.55 & 7.70 & 0.00 \\
\hline Corn straw & 94.46 & 89.83 & 10.17 & 5.13 & 36.43 & 0.63 \\
\hline Calliandra leaf meal & 93.67 & 92.37 & 7.63 & 23.16 & 12.08 & 3.90 \\
\hline
\end{tabular}

Feed Analysis result from Laboratory of Animal Feed and Nutrient, Faculty of Animal Science, University of Brawijaya (2019).

*) Based on $100 \%$ Dry Matter

\subsection{Data analysis}

The research data were analysed using a Randomized Block Design (RBD) and continued with Duncan's Multiple Range Test (DMRT). 


\section{Results and discussion}

\subsection{Proximate profile}

Based on the analysis of the nutrient content of the feed, the results were not too significant for the range of DM, CP, CF, EE, and OM. The different analysis results were caused by corn straw, calliandra leaf meal, and concentrate in each treatment. Corn straw has a low CP content, so it is necessary to apply technology such as preparing complete feed from feed ingredients containing high nutrients to cover the low nutrient content of corn straw. This is supported by Khoiriyah et al. [11], who stated that the addition of feed ingredients that contain high nutrients could increase the nutrient content of the feed. Table 2 shows the results of the complete feed nutrient content analysis for each treatment. The highest DM content was found in $\mathrm{T} 1$ of $93.64 \%$ compared to $\mathrm{T} 0$ of $92.53 \%$, T2 of $93.11 \%$ and $\mathrm{T} 3$ of $92.60 \%$, and T4 of $92.72 \%$. Daning and Foekh [12] explain that the high and low DM content is affected by the harvesting time of the fodder plant. While the OM content showed the following results: T0 was $93.38 \%$, T1 was $93.06 \%$, T2 was $93.15 \%$, and T3 was $93.33 \%$, and T4 was $93.27 \%$, with the highest percentage of content organic matter was in the T0 (control diet) which was $93.38 \%$.

Table 2 shows the results of the complete feed nutrient content analysis for each treatment. The treatment feed with the highest $\mathrm{CP}$ content was found in treatment $\mathrm{T} 3$, which had the highest crude protein value of $15.95 \%$ compared to T0, T1, and T2 and T4 with $15.41 \%, 15.65 \%$, and $14.35 \%$, and $15.03 \%$, respectively. The increase in crude protein content in complete feed can be affected by the ingredients of complete feed and calliandra leaves [13]. The crude fibre content of complete feed based on corn straw in this study showed results ranging from $17.123 \%$ to $19.98 \%$, the high and low content of CF was affected by the content of lignin, cellulose, and hemicellulose owned by forage fodder as feed ingredients for complete feed [10].

In this study, the addition of $3 \%$ or $30 \mathrm{~g} / \mathrm{kg} \mathrm{DM}$ of myristic acid was based on the research of [3]. The higher addition of myristic acid in the diet significantly affected the decrease in the value of feed degradation and increased the crude fat content in the treated feed. Compared with the results of this study, it showed that the highest EE content in T1 was $3.72 \%$ compared to T0 $(3.71 \%)$ and T2 $(3.65 \%)$, while the lowest crude fat content was in treatment $\mathrm{T} 4$, which was $2.78 \%$.

Table 2. Nutrient content of diet treatments

\begin{tabular}{|l|c|c|c|c|c|}
\hline \multirow{2}{*}{\multicolumn{1}{|c|}{ Nutrient composition (\% DM) }} & \multicolumn{5}{c|}{ Diet Treatments } \\
\cline { 2 - 6 } & T0 & T1 & T2 & T3 & T4 \\
\hline Dry matter (DM) & 92.53 & 93.64 & 93.11 & 92.60 & 92.72 \\
\hline Crude Protein (CP) & 15.41 & 15.65 & 14.35 & 15.95 & 15.03 \\
\hline Crude Fiber (CF) & 17.12 & 19.19 & 19.98 & 19.97 & 19.64 \\
\hline Extract Ether (EE) & 3.71 & 3.72 & 3.65 & 2.89 & 2.78 \\
\hline Organic Matter (OM) & 93.38 & 93.06 & 93.15 & 93.33 & 93.27 \\
\hline
\end{tabular}

Feed Analysis result from Laboratory of Animal Feed and Nutrient, Faculty of Animal Science,

University of Brawijaya (2019) 
Effect of myristic acid supplementation and calliandra leaf meal substitution (Calliandra calothyrsus) as a tannin condensate source in corn straw-based complete feed on dry matter degradation (DMD). Based on the results of the analysis showed that the addition of myristic acid and calliandra leaf meal (Calliandra calothyrsus) as a source of tannin content in corn straw-based complete feed (Zea mays) gave a significant difference $(\mathrm{p}<0.05)$ to the value of dry matter degradation (DMD). Further tests using Duncan's test showed that treatment T0 was not significantly different from $\mathrm{T} 1$ and $\mathrm{T} 4$, while $\mathrm{T} 1$ was significantly different at the $5 \%$ level $(\mathrm{p}<0.05)$ with T2 and T3. Dry matter degradation in T2 and T3 treatments gave no significant effect. The result indicates that differences in the composition of calliandra leaf meal affect the value of dry matter degradation (DMD). Table 3 explains the average dry matter degradation value (DMD) of the four treatments showing that $\mathrm{T} 3$ treatment has the highest average degradation value of $60.18 \%$, when compared to the average dry matter degradation value of T0 (48.37\%), T1 (49.69\%), and T2 (57.15\%) and T4 (50.41\%). The results of dry matter degradation in each treatment gave different values caused by the high and low crude fibre and crude protein content in each treatment. According to Wijayanti [14], $\mathrm{CF}$ content affects the degradation value because feed containing high CF content reducing feed digestibility.

Table 3 shows the results of the analysis of the dry matter degradation value of the feed. It was known that the highest dry matter degradation value (DMD) was in the T3 treatment feed (complete feed $+15 \%$ calliandra leaf meal $+30 \mathrm{~g} / \mathrm{kg}$ myristic acid). Increasing the level of giving calliandra leaf meal to the feed can increase the value of feed degradation. Lawa et al. [15] about the effect of adding white kabesak leaves on feed consumption and weight gain for Kacang goats, degradation, body weight gain, and feed conversion. Based on the study results, it was found that the crude fat content of each treatment did not differ much; this was presumably due to the myristic acid content added at the same level. Soy oil calcium levels in Bali cattle rations with proportions of $2.5 \%, 5 \%$, and $7.5 \%$ did not significantly affect the value of dry matter and organic matter degradation [16].

\subsection{Nutrient degradability profile}

Based on the results of the analysis showed that the addition of myristic acid and calliandra leaf meal (Calliandra calothyrsus) as a source of tannin content in corn straw-based complete feed (Zea mays) gave no significant effect $(\mathrm{p}>0.05)$ on the value of organic matter degradation. The range of organic matter that cannot be digested properly results in the value of organic matter degradation not being significantly different $(\mathrm{p}>0.05)$.

Table 3. Average value of dry matter degradability (DMD)

\begin{tabular}{|c|c|}
\hline Treatments & Dry Matter Degradability (\%) \\
\hline T0 & $48.37 \pm 2.38^{\mathrm{a}}$ \\
\hline T1 & $49.68 \pm 2.66^{\mathrm{a}}$ \\
\hline T2 & $57.14 \pm 3.75^{\mathrm{b}}$ \\
\hline T3 & $60.18 \pm 1.89^{\mathrm{b}}$ \\
\hline T4 & $50.41 \pm 4.35^{\mathrm{a}}$ \\
\hline
\end{tabular}

Note: Different superscripts in the same column show significant differences at the $5 \%$ level $(\mathrm{p}<0.05)$. 
Table 4. The average value of organic matter degradability

\begin{tabular}{|c|c|}
\hline Treatments & Organic matter degradability (\%) \\
\hline T0 & $57.33 \pm 8.19$ \\
\hline T1 & $60.58 \pm 8.97$ \\
\hline T2 & $63.63 \pm 5.25$ \\
\hline T3 & $61.38 \pm 6.63$ \\
\hline T4 & $59.27 \pm 8.22$ \\
\hline
\end{tabular}

Note: The treatment showed that it gave no significant difference at the $5 \%$ level $(\mathrm{p}>0.05)$

Based on the results of the analysis showed that the addition of myristic acid and calliandra leaf meal (Calliandra calothyrsus) as a source of tannin content in corn strawbased complete feed (Zea mays) gave no significant effect $(\mathrm{p}>0.05)$ on the value of organic matter degradation. The range of organic matter that cannot be digested properly results in the value of organic matter degradation not being significantly different $(p>0.05)$.

Table 4 shows the average value of organic matter degradation (OMD) from the four treatments, namely the average value of organic matter degradation in T2 treatment, which was the highest result of $63.63 \%$. While for treatment T0 $57.33 \%$, T1 $60.58 \%$, T3 $61.38 \%$ and T4 59.27\%. The average value of organic matter degradation is higher than that of dry matter degradation. Table 4 explains that the average value of organic matter degradation has increased along with calliandra leaf meal. The highest average value was found in the T2 treatment with the composition of complete feed ( $40 \%$ corn straw $+50 \%$ concentrate $+10 \%$ calliandra leaf meal) + myristic acid $30 \mathrm{~g} / \mathrm{kg}$ DM diet). The average dry matter degradation value and the average organic matter degradation value (OMD) has a not too significant difference. The opinion of Trisnadewi et al. [13] states that the degradation value of dry matter and organic matter is always in harmony or not much different; this is because most dry matter is composed of organic matter.

The addition of fatty acids in complete feed can increase the value of organic matter degradation (OMD). It is known that the average results of the degradation of organic matter (OMD) are not significantly different, presumably due to the composition of the addition of the same myristic acid. This is supported by Sany et al. [16] stated that the effect of fish oil and L-carnitine supplementation in fermented yellow corn feed on feed degradation and quail performance showed that the addition of lemuru fish oil and L-carnitine as much as $4 \%$ could increase the value of dry matter degradation and organic matter degradation. The value of T0 (basal feed) was $59.20 \%$, T1 (basal feed + fermented yellow corn) was $65.75 \%$, while the dry matter degradation value of T4 (basal feed $+4 \%$ lemuru fish oil) was $72.08 \%$.

\section{Conclusion}

The replacement of concentrate with calliandra leaf meal affects the percentage of feed ingredients that make up the concentrate, affecting the treatment feed's protein content. The use of calliandra leaf meal and the addition of myristic acid to complete feed based on corn straw can increase the value of dry matter degradation (DMD) and organic matter degradation (OMD). The highest dry matter degradation value was found in T3, namely the use of $15 \%$ calliandra leaf meal and myristic acid $30 \mathrm{~g} / \mathrm{kg}$ DM feed with a DMD value of $60.18 \%$. In contrast, the highest organic matter degradation value was found in T2, namely the use of $10 \%$ calliandra leaf meal and myristic acid $30 \mathrm{~g} / \mathrm{kg} \mathrm{DM}$ diet with an organic matter degradability value of $63.63 \%$. We suggested use of complete feed according to the best treatment, namely T3 (15\% calliandra leaf meal + myristic acid $30 \mathrm{~g} / \mathrm{kg} \mathrm{DM}$ diet). It is necessary to continue with research using livestock to determine livestock productivity. 


\section{References}

1. W.P. Hertawan, Jurnal Peternakan Indonesia 120 (2018)

2. S. E. Hook, A.D.G Wright, B.W. Archaea 1 (2011)

3. S. Chuzaemi, Mashudi, Livest. Anim. Res. 18 (2020).

4. Yanuartono, S. Indarjulianto, H. Purnamaningsih, A. Nururrozi, S. Raharjo. Jurnal Sains Peternakan Indonesia 14 (2019)

5. E. Gustiani, K. Permadi. Jurnal Peternakan Indonesia 17 (2015)

6. O. Sjofjan, D. N. Adli, M.H. Natsir, Y. F. Nuningtyas, T. S. Wardani, I. Sholichatunnisa, S. N. Ulpah, O. Firmansyah, Jurnal Ilmu Ternak dan Veteriner 26 (2021)

7. A. Irsyamawati, S. Chuzaemi, Hartutik, Jurnal Ilmu-Ilmu Peternakan 21 (2011)

8. Yurleni, R. Priyanto, Jurnal Ilmu-Ilmu Peternakan 19 (2016)

9. M. Hambakodu, A. Kaka, Y. T. Ina, Jurnal Ilmu dan Teknologi Peternakan Tropis 7 (2020)

10. M. Khoiriyah, S. Chuzaemi, H. Sudarwati, Jurnal Ternak Tropika 17 (2016)

11. D.R.A Daning, B. Foekh, Sains Peternakan 16 (2018)

12. A. A. A. S. Trisnadewi, I. G. L. O. Cakra, I. W. Wirawan, I. M. Mudita, N. L. G. Sumardani, Pastura 3 (2014).

13. E. Wijayanti, F. Wahyono, Surono. Animal Agricultural 1 (2012)

14. E. D. W Lawa, Marjuki, Hartutik, S. Chuzaemi, J. Indones. Trop. Anim. Agric. 42 (2017)

15. A. W. Sany, S. R. Heswantari, Sudibya, S. H. Purnomo, A. Hanifa, Buletin Peternakan 39 (2015) 